УДК 328(091)

ББК 67

\title{
УПРАВЛЕНЧЕСКИЕ СТРУКТУРЫ БУРЯТИИ И РАЗВИТИЕ РЕГИОНА В НАЧАЛЕ 1980-Х ГОДОВ
}

В исследуемый период отмечены активные и значимые процессы в общественно-политической и экономической жизни республики. Принятая Конституция Бурятской АССР оказала позитивное влияние на дальнейшее развитие автономной республики. Региональные органы совершенствовали взаимодействие с союзными и федеральными органами власти и управления в условиях доминирования партийных структур. Происходили существенные изменения в структуре экономического развития региона, создавались новые отрасли индустрии и промышленные предприятия.

Ключевые слова: конституционные изменения, партийные органы и государственные органы Бурятии, политические решения, экономическое и социальное развитие региона, предприятия.

E.T. PROTASOV

\section{MANAGEMENT STRUCTURES OF THE REPUBLIC OF BURYATIA AND DEVELOPMENT OF THE REGION IN THE EARLY 1980-ies}

In analyzed period marked by active and meaningful processes in social, political and economic life of the Republic. Adopted Constitution of the Buryat ASSR has had a positive impact on the further development of the Autonomous Republic. Regional bodies to improve interaction with federal and federal authorities and governance under the dominance of party structures. There were significant changes in the structure of economic development of the region, creation of new industries and industrial enterprises.

Keywords: constitutional changes, party and Government authorities of Buryatia, political decisions, economic and social development of the region, businesses.

Важным политическим событием в истории любого цивилизованного государства является подготовка и принятие ее Конституции, определяющей правовые основы государственности. Она определяет последовательное развитие всего конституционного законодательства, регулирует правовые отношения в обществе. Оценивая подготовку, утверждение Основного Закона Бурятской АССР в мае 1978 г. следовало сказать, что государственными, партийными, общественными организациями была проведена огромная работа. В ее текст включались новые разделы 
и главы, а ряд статей изменены и дополнены. Подробно определялось правовое положение, регламентировался порядок и формы деятельности Верховного Совета и его Президиума, а также Совета Министров автономной республики, которая стала общенародным государством. Советы народных депутатов различных уровней образовали единую систему государственной власти, являясь политической основой общества. Национальная государственность Бурятии была ограничена. Согласно знаменитой статьи 6 КПСС была определена ядром политической системы страны, руководящей и направляющей силой в жизни общества, что конституционно закрепила однопартийную систему и недемократический путь развития государства.

15-16 января 1981 г. состоялась очередная XXXI областная отчетно-выборная партийная конференция. Активный предсъездовский настрой, трудовые почины принимались и поддерживались на многих предприятиях и организациях весь предыдущий год. Повестка названной конференции была традиционной. В ее работе приняли участие заместитель заведующего сельскохозяйственным отделом ЦК КПСС К.И. Капустян, министр транспортного строительства СССР И.Д. Соснов [1, д. 9036, л. 1]. После отчетного доклада выступил Председатель Совета Министров республики В.Б. Саганов по вопросам основных направлений развития народного хозяйства СССР и Бурятской АССР на 1981-1985 г.. Были избраны члены пленума обкома в количестве 201 человек, а на организационном пленуме секретарями обкома стали А.У. Модогоев, В.Г. Бирюков, А.А. Бадиев, Л.В. Потапов, В.Ф. Лысов [1, д. 9036, л. 283-284].

Как отмечалось на конференции партийная организация республики объединяла в своих рядах 48628 членов и кандидатов в члены КПСС. Более 42 \% всего состава областной партийной организации составляли рабочие и колхозники, 17 \% инженеры, техники и мастера, 6 \% - врачи и учителя. Насчитывалось 1315 первичных парторганизаций, 146 организаций возглавлялось парткомами [1, д. 9036, л. 41]. На конференции была отмечена работа передовых во многих отношениях предприятий и организаций, подведомственных различным министерствам и ведомствам. Это Тонкосуконный комбинат, Приборостроительный и Ново-Брянский заводы, строительные организации БАМа, Баргузинский леспромхоз, совхозы «Оерский», «Тулдунский», «Бодонгутский», «Улюнханский», колхозы «Искра» и «Маяк» Улан-Удэнского, «Коммунизм» Еравнинского, «Сибиряк», имени Ленина Тункинского районов и многие другие. Повысился уровень руководства хозяйственным и культурным строительством в Октябрьском, Бичурском, Заиграевском, закаменско районах [1, д. 9036, л. 42]. Делегат И.Д. Соснов отметил, что за успешное выполнение социалистических оязательств и целевых задач по вводу в эксплуатацию важнейших народнохозяйственных объектов Указами 
Президиума Верховного Совета СССР в 1980 г. присвоено высокое звание Героя Социалистического труда шести транспортным строителям, а государственных наград удостоены 790 человек [1, д. 9036, л. 94].

В решениях конференции было отражено, что государственным и партийным организациям, хозяйственным органам необходимо повышать спрос с кадров за выполнение установленных заданий, строгое соблюдение государственной дисциплины. Одновременно в докладе на конференции подчеркивались серьезные недостатки в работе региональных министерств мелиорации и водного хозяйства, сельского хозяйства, объединения «Бурятжелезобетон», Управления строительных материалов и других ведомств. Они слабо повышали ответственность работников аппарата за выполнение директивных решений партии и правительства, не проводили должной работы по повышению ответственности должностных лиц за порученный участок работы, нередко мирились со случаями невнимательного, бюрократического к запросам и нуждам подведомственных предприятий, к письмам и сигналам трудящихся. Руководители Селенгинского, Кяхтинского, Окинского и Джидинского районов медленно совершенствовали стиль и методы работы в соответствии с современными требованиями, недостаточно глубоко вникали в состояние экономики района, нередко упускали из поля зрения решающие участки [1, д. 9036, л. 36]. Вместе с тем исследователь В.М. Кудров обращал внимание на расширение каналов контроля за производством: «Отсутствие встроенных экономических стимулов в известной мере компенсировалось механизмами контроля и управления. При этом истинным «нововведением» стало многократное дублирование структур власти и контроля, особенно в экономике. Наряду с ведомственным руководством и контролем каждое предприятие руководилось партийными и региональными властями, опекалось партийным народным контролем, подразделениями КГБ, МВД, ЦСУ, Минфина, Госбанка, различными инспекциями и т.д.» [4, с. 67].

В фреврале 1981 г. в Москве проходил XXVI съезд КПСС, в работе которого приняли участие 15 делегатов от областной партийной организации, в том числе модельщик Улан-Удэнского авиазавода В.И. Бардунаев, Герои социалистического труда - вальщик леса СМП-608 треста «Нижнеангарсктрансстрой» В.И. Аксенов, старший чабан колхоза имени Карла Маркса О.Э. Сангадиева, директор Тонкосуконного комбината К.П. Альцман, а также первые руководители автономной республики [1, д. 9036, л. 258-259]. Партийный форум подвел итоги завершившейся пятилетки и наметил новые рубежи экономического и социального развития страны.

Решения съезда были восприняты коммунистами и всеми трудящимися какбоевая программа действий, ясно раскрывающая перед страной перспективы уверенного продвижения вперед зрелого соци- 
алистического общества, указывающая конкретные пути реализации поставленных целей и задач, раскрывающая огромные материальные и духовные возможности страны [1, д. 9036, л. 13]. Членом ЦК КПСС на съезде вновь был избран А.У. Модогоев. Фактически это был последний «брежневский» съезд, явившийся своеобразной кульминацией «застойного» периода.

После окончания партийного форума по инициативе партийных органов состоялись семинары пропагандистов, идеологический актив активно включился в работу по разъяснению основных съездовских материалов. В марте состоялось собрание областного и Улан-Удэнского городского партийных активов, обсудивших решения съезда и определивших конкретные направления работы по их выполнению. В докладе А.У. Модогоев отмечал, что «... продолжается процесс сближения всех классов и социальных групп советского общества. Повышается роль рабочего класса, что, безусловно, связано с ростом его идейно-политической зрелости, образованности, профессионального уровня. Ныне в стране около 80 миллионов, т.е. две трети занятого населения - рабочие. По мере индустриализации сельского хозяйства главные перемены происходят в жизни колхозного крестьянства. На селе становится все больше механизаторов, связанных с техникой. Преодолеваются различия в социальном положении рабочего и крестьянина. Все более значительную роль не только в науке, образовании и культуре, но и в производстве играет интеллигенция, численность которой быстро растет» [1, д. 9036, л. 41-42].

Повышению эффрективности производства способствовала проводимая работа по претворению в жизнь постановлений ЦК КПСС и Совета Министров СССР от 12 июля 1979 г. «О совершенствовании хозяйственного механизма и задачах партийных и государственных органов», «Об улучшении планирования и усиления воздействия хозяйственного механизма на повышение эффективности производства и качества работы» [3]. Они определяли важные шаги, направленные на дальнейшее совершенствование планового руководства экономикой, управления производством, повышение творческой инициативы трудовых коллективов. С целью поднять уровень планирования и хозяйствования предусматривалось усилить роль перспективного планирования, усовершенствовать систему планируемых показателей и экономических нормативов в сфере производства, труда и социального развития, финансов и капитального строительства, внедрения новой техники, материально-технического обеспечения. Партийным, советским, хозяйственным, профсоюзным и комсомольским организациям предлагалось рассматривать осуществление мер по совершенствованию хозяйственного механизма как крупную хозяйственно-политическую задачу, повышать организованность и слаженность работы всех звеньев экономики, укреплять государствен- 
ную, производственную и трудовую дисциплину, поднимать ответственность кадров за выполнение планов и договорных обязательств. Конкретные задачи по их претворению в жизнь обсуждались на пленуме обкома партии и собрании партийно-хозяйственного актива 25 апреля 1981 г. [1, д. 9077, л. 7]. В апреле того же года были проведены объединенный пленум творческих союзов писателей, художников, композиторов республики и Бурятского отделения Всероссийского театрального общества, где также обсуждались вопросы выполнения решений съезда.

12 мая 1981 г. состоялся пленум обкома партии, специально обсудивший вопросы выполнения постановления ЦК КПСС и Совета Министров СССР «О дальнейшем развитии производительных сил Бурятской АССР в 1981-1985 гг. и на период до 1990 г.». В его работе приняли участие ответственные работники Госплана СССР и Госплана РСФСР Г.С. Ущербов, В.Т. Матузов, А.К. Кулагин, начальник Управления Восточно-Сибирской железной дороги Ш.А. Цынцадзе, начальник Управления Байкало-Амурской железнодорожной магистрали Л.В. Лотарев, генеральный директор объединения «Востсибуголь» В.З. Беседин, начальник Главного управления материально-технического снабжения Восточно-Сибирского региона В.И. Шишов [1, д. 9077, л. 27] и другие хозяйственные руководители различных уровней. Были приняты развернутые мероприятия по группам отраслей. В республике в одиннадцатой пятилетке предстояло увеличить производство промышленной продукции на 30 процентов. Предусматривались высокие темпы развития топливно-энергетического комплекса, завершение строительства Гусиноозерской ГРЭС, строительство ТЭЦ-2 в городе Улан-Удэ, освоение Тугнуйского угольного месторождения. Намечены были высокие темпы развития машиностроения и приборостроения, большие работы по реконструкции завода «Электромашина», Джидинского вольфрамо-молибденового и Озерного горно-обогатительного комбинатов [1, д. 9041, л. 2-3]. Намечалось строительство завода легкобетонных конструкций, крупнопанельного домостроения в Улан-Удэ на 140 тыс. кв. метров жилой площади, заводов асфальтобетонного, железобетонных изделий в Каменске и Курумкане, стеновых материалов в Гусиноозерске. В то же время в соответствии с постановлением ЦК КПСС и Совета Министров СССР «О мерах по дальнейшему улучшению работы железнодорожного транспорта в районах Сибири и Дальнего Востока» и «Об улучшении ремонта подвижного состава железных дорог» крупные целевые задачи предстояло решить тресту «Улан-Удэтрансстрой», главной задачей которого являлась реконструкция ЛВРЗ, а также транспортными строителями намечено было осуществить строительство железной дороги Могзон-Озерный протяженностью 162 км. Большое внимание уделялось созданию трудовых коллективов строителей и закреплению в них профрессиональных кадров. Вопросы дальнейшего развития города Улан-Удэ, размещения промышленных, коммунальных, 
жилых и соцкультбытовых объектов были определены в новом генеральном плане города, который был завершен разработкой и согласованием в Министерствах СССР и РСФСР и окончательным утверждением в Совете Министров РСФСР [1, д. 9041, л. 19].

Развивая социальную сферу, в восьмидесятые годы намечено было построить общеобразовательные школы на 23 тыс. мест, детские дошкольные учреждения на 12,6 тыс. мест, профтехучилища на 2710 мест, ввести в строй действующих учебно-производственные помещения вузов общей площадью 17900 м², общежитий на 1730 мест, столовых на 300 посадочных мест [1, д. 9041, л. 23-24]. Серьезные задачи предстояли в деле улучшения медицинского обслуживания населения с целью направить усилия медицинской помощи населению, повысить эффективность работы органов и учреждений здравоохранения, добиваться широкого внедрения в клиническую практику современных методов диагностики и лечения больных. Не последнее место в цепи задач, стоявших перед медиками, занимали вопросы строительства. За пятилетие намечено было построить больниц на 900 коек. Планировалось расширить курорты, санатории, профилактории, оздоровительные площадки для детей, пионерские лагеря. Намечалось также решение ряда других вопросов в отраслях народного хозяйства региона.

ЦК КПСС и Совет Министров СССР в рассматриваемом постановлении выдвинули большие задачи перед научными учреждениями республики. Коллективу Геологического института БФ СО АН СССР необходимо было подготовить общую концепцию размещения полезных ископаемых на территории республики, выработать эффрективную методику их поиска и определения запасов, провести соответствующие технологические проработки по выявленным месторождениям. Совместными усилиями ученых института биологии Бурятского филиала Сибирского отделения, научно-исследовательского института сельского хозяйства и сельскохозяйственного института предстояло обосновать продовольственную программу до 1990 г. Бурятский НИИСХ призван был развернуть комплексные исследования почвенно-земельных, растительных, животных и сельскохозяйственных ресурсов республики, разработать научные основы повышения продуктивности пашен, лугов, пастбищ, особенно поливных и животноводства в условиях Забайкалья. Институт естественных наук и Восточно-Сибирский технологический институт должны были активнее участвовать в создании новых видов материалов, машин и аппаратов для предприятий, хозяйств и строек республики, развернуть исследования, направленные на повышение энерго- и механовооруженности предприятий, более рациональное использование трудовых ресурсов, экономию топлива, энергии и сырья. Ученым-экономистам предстояло детально исследовать факторы, способствующие переводу народного хозяйства республики в 1981-1985-х гг. на рельсы интенсив- 
ного развития на путях повышения производительности труда. Важно было выяснить и раскрыть проблемы формирования Восточно-Бурятского и Северо-Байкальского территориально-производственных комплексов, развернуть исследования по экологии и охране окружающей среды, рациональному природопользованию в бассейне озера Байкал, прежде всего лесопользованию и использованию водных ресурсов [5, с. 91]. Необходимо было укреплять связь науки с производством, расширить практику заключения договоров о содружестве с предприятиями, определив из них базовые для первоочередного внедрения результатов научных исследований в производство. Бурятскому филиалу СО АН СССР следовало усилить координацию научных исследований учреждений академической, отраслевой и вузовской науки, направив их на решение наиболее актуальных научно-технических проблем развития производительных сил республики, формировать крупные комплексно-целевые научные программы, всемерно развивать системный подход к решению важнейших экономических задач. Для более успешной работы в этом направлении при обкоме партии и Совете Министров республики в 1981 г. был создан научный совет из представителей научных учреждений, партийных, советских органов и хозяйств [1, д. 9041, л. 25-26]. Партийный пленум еще раз подчеркнул, что новые важные задачи требовали от государственных и партийных организаций, хозяйственных органов поднять всю организаторскую и политическую работу на новую ступень.

Коллектив судостроительного завода принял социалистическое обязательство по экономии материальных, энергетических и трудовых ресурсов на базе широкого использования достижений науки и техники. Инициатива судостроителей нашла понимание и поддержку в коллективе Тонкосуконного комбината, также вступившими в борьбу за экономию ресурсной базы. Активная позиция производственников нашла одобрение у бюро обкома, высоко оценившего очередной почин [1, д. 9044, л. 21]. В декабре 1981 г. на Бурятском участке БАМа первый поезд с почетными пассажирами открыл рабочее движение от Северобайкальска до Уояна. Перед этим событием прошла третья Всесоюзная научно-практическая конференция по проблемам хозяйственного освоения БАМа [1, д. 9947, л. 21].

Уделяя серьезное внимание вопросам социалистического соревнования, Улан-Удэнский горком партии на своем пленуме «О совершенствовании партийного руководства социалистическим соревнованием на предприятиях и стройках города в свете решений XXVI съезда КПСС и задачах партийных организаций по успешному выполнению обязательств, принятых на 1981 год» [1, д. 9984, л. 2-20] принял решение об усилении работы и применении новых современных методов организации этой передовой формы социалистического труда. Этому же вопросу была посвящена и научная конференция, прошедшая 13 октября 1981 г. 
по инициативе обкома партии, под девизом «XXVI съезд КПСС о проблемах социалистического труда и современная идеологическая работа» [2, л. 4-18]. В ней приняли участие ученые из институтов Академии наук СССР, Академии общественных наук при ЦК КПСС, Высшей комсомольской школы при ЦК ВЛКСМ, общества «Знание», ученые и практические работники Бурятии. Конференция подчеркнула необходимость укрепления современной идеологической подготовки трудящихся и молодежи, формирование достойного кадрового резерва в республике, а также особенного усиления идеологической работы на строительстве БАМ. В канун нового 1982 г. группе ветеранов труда были вручены знаки «50 лет пребывания в КПСС». Среди награжденных участник Октябрьской революции В.И. Шатилов, а также участники социалистического строительства в республике, руководящие работники государственных и партийных органов разных периодов Н.И. Мункоев, Г.Ц. Бельгаев, Т.П. Дычко, С.Я. Ербанова, К.Т. Барабанов, Е.А. Широких-Полянская.

Таким образом, согласно новых конституционных норм Бурятская АССР были объявлена социалистическим общенародным государством. Более конкретно устанавливались порядок и формы деятельности органов законодательной и исполнительной власти республики. Советы народных депутатов стали политической основой общества. Национальная государственность Бурятии была ограничена. КПСС стала ядром политической системы, руководящей и направляющей силой в жизни общества. Следует отметить, что это был последний Основной Закон, сохранивший преемственность идей и принципов предыдущих советских Конституций. В исследуемый период вследствие целенаправленной работы органов государственной власти и управления по интенсивному развитию производительных сил сибирских регионов существенно возросли общий экономический уровень Бурятской АССР и ее интеграция в макроэкономический механизм государства. Поступательное увеличение капитальных вложений определяло значительное улучшение материально-технической базы промышленности, повышение уровня индустриализации сельскохозяйственного производства, повышение технического уровня строительной отрасли, улучшение работы транспорта в регионе. В известной мере этому способствовали рекомендациии научного сообщества. Но возрастали количественные народнохозяйственные показатели, сопровождаемые в основном увеличением инвестиций, использованием дополнительных ресурсов и рабочей силы. Являясь частью единого экономического комплекса, хозяйство Бурятии отражало все основные противоречия в развитии производительных сил страны. Для нее были также характерны значительная несбалансированность отраслевой структуры хозяйства, существенная доля оборонного сектора экономики, слабая приспособляемость к изменениям и рыночным отношениям. 


\section{Список использованной литературы и источников}

1. Государственный архив Республики Бурятия (ГАРБ). - Ф. П-1. — Оп. 1.

2. ГАРБ. - Ф. П.2. - Оп. 15. - Д. 2.

3. КПСС в резолюциях и решениях съездов, конференций и пленумов ЦК (1898-1986). - 9-е изд., доп. и испр. — М. : Изд-во полит. лит., 1987. - Т. 13. C. 353-396.

4. Кудров В. М. Крах советской модели экономики / В. М. Кудров. - М. : ООО «Издат. центр науч. и учеб. программ», 2000. - 98 с.

5. Цыкунов Г. А. Эвоюция научных взглядовна теорию и практику ТПК / Г.А.Цыкунов // Иркутский историко-экономический ежегодник: 2017. - Иркутск : Изд-во БГУ, 2017. — С. 89-96.

\section{Информация об авторе}

Протасов Евгений Тарасович — кандидат исторических наук, доцент, кафедра менеджмента, Бурятская государственная сельскохозяйственная академия, 670024, г. Улан-Удэ, ул. Пушкина, 8; e-mail: protasov-evg@mail.ru

\section{Author}

Eugene T. Protasov -PhD in History, Associate Professor, Chair of State and Municipal Management, Buryat State Agricultural Academy, 8 Pushkin St., 670024, Ulan-Ude, Russia; e-mail: protasov-evg@mail.ru 